\title{
THE ACID CATALYZED REACTION OF $\alpha$-PINENE OVER Y-ZEOLITE
}

\author{
Nanik Wijayati ${ }^{1,2,}$, Harno Dwi Pranowo ${ }^{2}$, Jumina $^{2}$, and Triyono ${ }^{2}$ \\ ${ }^{1}$ Department of Chemistry, State University of Semarang, Jl. Raya Sekaran Gunungpati Semarang 50229 \\ ${ }^{2}$ Department of Chemistry, Faculty of Mathematics and Natural Sciences, Universitas Gadjah Mada, \\ Jl. Sekip Utara, Yogyakarta 55281
}

Received April 10, 2012; Accepted October 2, 2012

\begin{abstract}
The hydration of $\alpha$-pinene has been studied in the presence of $Y$-zeolite $(S i / A l=2.89)$ as a solid acid catalyst. The reaction was performed in batch reactor in isopropyl alcohol at various temperature and reaction time with magnetic stirrer. The acid catalyst hydration reaction of $\alpha$-pinene yields a complex mixture of monoterpenes, alcohols and hydrocarbons. The selectivity of $\alpha$-terpineol (the monocyclic alcohol) as main product was $59.20 \%$ with a conversion of $83.83 \%$ and the non alcoholic as the isomerization co-product as $30 \%$ after 60 min at $65{ }^{\circ} \mathrm{C}$. The conversion and selectivity to $\alpha$-terpineol increase significantly with in increase in temperature and reaction times.
\end{abstract}

Keywords: Y-Zeolite; a-pinene; $\alpha$ terpineol; hydration

\begin{abstract}
ABSTRAK
Hidrasi a-pinena telah dilakukan dengan menggunakan zeolit $Y(S i / A l=2.89)$ sebagai katalis asam padat. Reaksi dilakukan dalam reaktor batch dengan pengaduk magnetik dalam pelarut isopropil alkohol dengan variasi temperatur dan waktu reaksi. Reaksi hidrasi $\alpha$-pinena dengan katalis zeolit $Y$ menghasilkan campuran kompleks monoterpena, alkohol, dan hidrokarbon. Selektivitas a-terpineol (alkohol monosiklik) sebagai produk utama adalah $59.20 \%$ dengan konversi $83.83 \%$ dan non alkohol sebagai produk isomerisasi (30\%) diperoleh setelah 60 menit pada suhu $65{ }^{\circ} \mathrm{C}$. Konversi dan selektivitas ke a-terpineol meningkat secara signifikan dengan peningkatan temperatur dan waktu reaksi.
\end{abstract}

Kata Kunci: Zeolit Y; a-pinena; $\alpha$-terpineol; hidrasi

\section{INTRODUCTION}

The main product of the acid-catalyzed hydration of $\alpha$ - or $\beta$-pinenes, renewable raw materials obtained from pine gum, is $\alpha$-terpineol, which has many applications in the pharmaceutical and perfume industries [1-2]. The use of solid acid catalysts in the hydration/isomerisation reaction of $\alpha$-pinene has been widely studied in recent years. However, the high selectivity's with reasonable good activities have revealed to be difficult since pinenes are easily isomerized to large number of products. $\alpha-$ terpineol itself is also easily dehydrated and isomerized. By controlling the reaction variable, it is possible to make it to be highly selective towards the desired products. Many efforts have been put on research to develop clean processes to afford the selectivity [2-6]. Y-zeolite may have potential in improving the selectivity of $\alpha$ pinene in the reactions.

Some of the homogeneous catalysts exhibit poor performance as they increase the solubility of terpineol in the aqueous phase. Apart from this, complete separation of homogeneous acid from the product is

* Corresponding author. Tel/Fax : +62-81575579586

Email address : nanik_unnes@yahoo.com very difficult to be performed because dehydration of terpineol occurs in the downstream process [7$8,10,14]$. Hence, the use of heterogeneous catalyst is highly recommended for this reaction as it offers several engineering benefits and provides a favorable distribution of alcohol in the two liquid phase $[9,12]$.

Several studies on hydration of a-pinene using homogeneous and heterogeneous solid acids had been reported [7-10]. Vital et al. [4] reported the use of solid acid catalysts such as zeolites and impregnated phosphomolybdic acid (HPMo) on polymeric membranes for a-pinene hydration to give $100 \%$ conversion with selectivity for a-terpineol between $50 \%$ and $70 \%$ although it required $150 \mathrm{~h}$ of reaction time.

Patricia et al. [7] employed phosphotungstic acid $\left(\mathrm{HPW}_{12} \mathrm{O}_{40}\right)$ as catalyst and mixture of acetic acid and water as solvent for limonene and $\alpha$-pinene hydration. They studied the reaction under homogeneous and heterogeneous conditions with supported phosphotungstic acid on silica. The conversion of $90 \%$ was observed in the homogeneous reaction with selectivity of $85 \%$ for monocyclic and bicyclic alcohols

Nanik Wijayati et al. 
but the acid had to be recovered from the reaction liquid due to its strong acidity and contamination problems. Experiments with the supported catalyst showed considerable decrease in conversion and the appearance of large percentage of isomerization products. Román-Aguirre et al. [8] utilized oxalic and chloroacetic acid for the transformation of a-pinene and obtained conversion of $80 \%$ with selectivity of $70 \%$ for a-terpineol after $4 \mathrm{~h}$ but the dissolved acid had to be separated. Mochida et al. [9] reported the use of zeolites and obtained $100 \%$ conversion but with low selectivity for alcohols (about 57\%). Avila et al. [2] used the catalysts $\mathrm{TCA} / \mathrm{ZrO} \mathrm{rO}_{2} \cdot \mathrm{nH}_{2} \mathrm{O}$ in conversion of a-pinene into hydrocarbons with conversion of $57 \%$ and selectivity of $75 \%$ of total alcohol and it showed $57 \%$ selectivity for a-terpineol.

In this work, the hydration of $\alpha$-pinene using Y-zeolite as heterogeneous catalyst have been reported. Heterogeneous catalyst is a cleaner process, where the solid catalyst is easily separated from the reaction mixture.

\section{EXPERIMENTAL SECTION}

\section{Materials}

a-pinene and Y-zeolite were obtained from Sigma Aldrich Chemical Company, Australia. The zeolite (the ammonium form) was activated by heating them at $823 \mathrm{~K}$ for $5 \mathrm{~h}$ in a furnace.

\section{Instrumentation}

Analysis of the reaction products was performed by Gas Chromatography (GC) (Hewlett Pacard 5890 Series II equipped with flame ionization detector/FID). The column used was HP5 (\% phenyl methyl siloxane). The temperature of the column was adjusted to be $70{ }^{\circ} \mathrm{C}$ for $5 \mathrm{~min}$ and then increased to $280^{\circ} \mathrm{C}$ by $10^{\circ} \mathrm{C} / \mathrm{min}$. The carrier gas used was helium $(\mathrm{He})(0.1 \mu \mathrm{L} / \mathrm{min}$ flow). The injection and detection temperatures were set to be 280 and $300{ }^{\circ} \mathrm{C}$, respectively and the split mode was $1 / 100$.

The various components were characterized by FTIR and GC-MS instrument (QP2010S Shimadzu). The column used was AGILENT DB-5 I: $30 \mathrm{~m}$; id: $0.25 \mathrm{~mm}$ and the carrier gas used was helium. The temperature of the column was adjusted to be $60^{\circ} \mathrm{C}$ for $5 \mathrm{~min}$ and then increased to $280{ }^{\circ} \mathrm{C}$ by $10{ }^{\circ} \mathrm{C} / \mathrm{min}$. The injection and detection temperatures were set to be 290 and $300{ }^{\circ} \mathrm{C}$. Pressure: $10.9 \mathrm{kPa}$; Total flow: $80.0 \mathrm{~mL} / \mathrm{min}$; Column flow: $0.5 \mathrm{~mL} / \mathrm{min}$; linear velocity: $25.8 \mathrm{~cm} / \mathrm{sec}$; Purge flow: $0.3 \mathrm{~mL} / \mathrm{min}$; Splitter ratio: 158.5 .

The FTIR spectra of the Y-zeolite sample were recorded on a FTIR (Hitachi 270-50; Perkin Elmer Paragon 1000 PC; Shimadzu FTIR-8201PC) in the
$4000-500 \mathrm{~cm}^{-1}$ wave number range using $\mathrm{KBr}$ pellets. The determination of structure of the heterogeneous catalysts were done by X-ray diffractometer using a $D$ Max III (Rigaku) with Cu Ka radiation $(\lambda=1.5378 \mathrm{~A}$, $40 \mathrm{kV}, 30 \mathrm{~mA})$. The range of scanning angle $(2 \theta)$ was kept at $2-60^{\circ}$. BET surface area of the samples was estimated by using Quantachrome ${ }^{\circledR}$ ASiQwin $^{\mathrm{TM}}$, Autosorb iQ Station 1 instrument. The determination of images of catalyst was done by SEM (specifications: 1) $\mathrm{Pt}$ auto fine coater, Model: JEOL JFC-1600; Parameters: $20 \mathrm{~mA}, 30 \mathrm{sec}$ coating time; Pt thickness: approx. 5nm; 2) FESEM, Model: JEOL JSM-6701F, Voltage range: $0.1-30 \mathrm{kV}$, Magnification: 25X-650kX, Resolution: $1 \mathrm{~nm})$.

\section{Procedure}

\section{Catalyst characterization}

The crystalline structure of the Y-zeolite was studied by X-ray diffraction. The nature of the acid centers (Brønsted and Lewis) of the catalyst was studied using the adsorption of pyridine. The catalyst was impregnated with $2 \mathrm{~mL}$ of pyridine. The disk was left in an air flow for $24 \mathrm{~h}$ to eliminate the physisorbed pyridine. The presence of pyridine in catalyst was detected by FT-IR. Brønsted and Lewis sites were identified by bands at 1536 and $1440 \mathrm{~cm}^{-1}$, respectively. Surface area was obtained using conventional BET isotherm ( $\mathrm{p} / \mathrm{p} 0=0.05-0.3)$. External surface area and volume of mesopores were calculated from t-plot using Harkins-Jura master isotherm. Total pore volume was determined from adsorbed nitrogen at relative pressure 0.98 . The $\mathrm{N}_{2}$ adsorption-desorption isotherms was measured on Quadrasorb-SI surface area/pore size analyzers from Quantachrome Instruments. Samples were activated at $400{ }^{\circ} \mathrm{C}$ under vacuum overnight before measurements. A BJH model was used to obtain pore size distribution from the adsorption branches of the isotherms. The morphology of the materials was examined by scanning electron microscopy, SEM (JEOL JSM-6701F).

\section{Catalytic test}

The reactions were carried out in a glass reactor equipped with magnetic stirrer, sampling port, temperature bath, and condenser. A mixture of $1.84 \mathrm{mmol}$ of $\alpha$-pinene, $2.5 \mathrm{~mL}$ of $\mathrm{H}_{2} \mathrm{O}$, and $3.4 \mathrm{~mL}$ of isopropyl alcohol was loaded into reactor. The mixture was stirred and warmed up to the desired temperature. Once the desired temperature was reached, the $400 \mathrm{mg}$ of Y-zeolite catalyst was added into the reactor. The reaction products were analyzed by $\mathrm{GC}$ by taking samples at $10,20,30,60,120$, and $240 \mathrm{~min}$ after the addition of catalyst. The samples were taken at different interval of time to study the variation of 


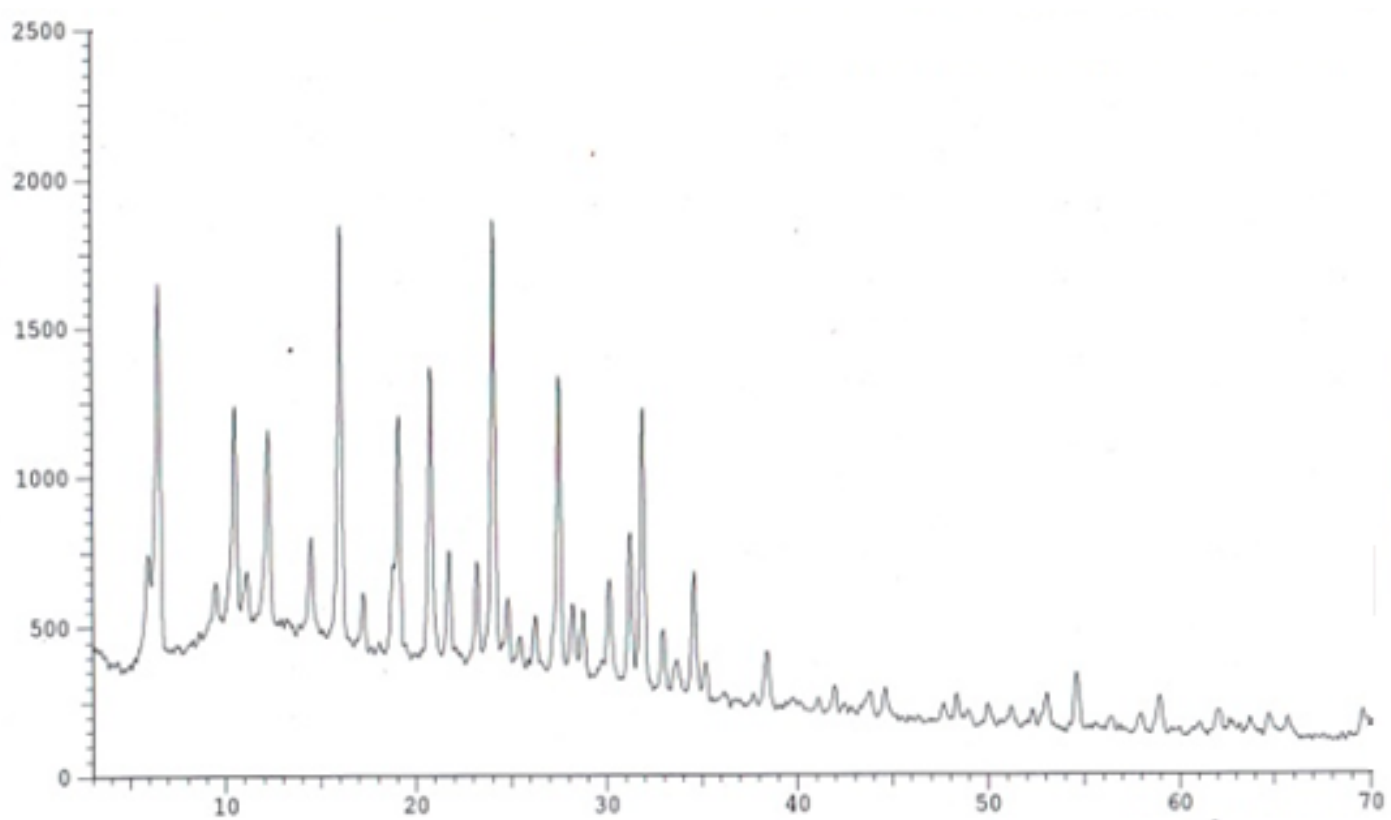

Fig1. XRD spectrum of Y-zeolite

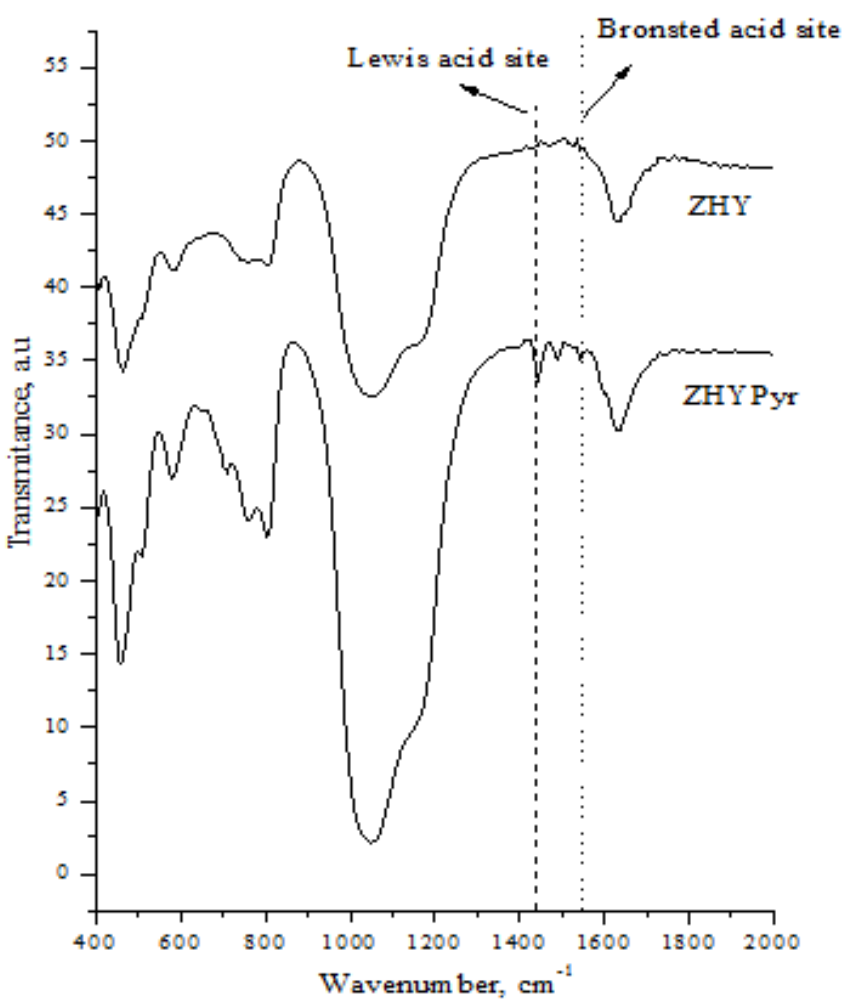

Figure 2. FT-IR spectrum of Y-Zeolite

Table 1. XRD Analysis

\begin{tabular}{clcc}
\hline Peak & $2 \theta(\mathrm{deg})$ & I/II & Intensity (Counts) \\
\hline 24 & 24.0582 & 100 & 1032 \\
19 & 20.7601 & 65 & 669 \\
15 & 16.0217 & 92 & 945 \\
3 & 6.5160 & 81 & 839 \\
\hline
\end{tabular}

reactant concentration and product. The samples were centrifuged at high speed of rotation (350 rpm) for about $10 \mathrm{~min}$ at ambient temperature to ensure that they were free of solid catalyst. Peak identification of the products was done by GC-MS analysis.

\section{RESULT AND DISCUSSION}

\section{Characterization of Catalyst}

\section{$X R D$-analysis of catalyst}

The crystalline structure of the Y-zeolite was analyzed by XRD (Fig. 1). The powder diffractogram of Y-zeolite showed reflection lines at $3^{\circ}, 15^{\circ}, 19^{\circ}$, and $24^{\circ}$ (Table 1 ) which was assigned to Y-zeolite (JCPDS (Joint Committee of Powder Diffraction Standard) files.

\section{Acidity by adsorption of pyridine}

The presence of Brønsted and Lewis sites was studied using the adsorption of pyridine with monitoring by FT-IR [11]. The band at $1543 \mathrm{~cm}^{-1}$ was assigned to the pyridinium ion formed on a Brønsted acid site, while the band at $1442 \mathrm{~cm}^{-1}$ corresponded to the pyridine coordinated to Lewis side centers (Fig. 2).

\section{Surface area and pore volume of Y-zeolite}

Nitrogen adsorption-desorption measurement was carried out at $-196{ }^{\circ} \mathrm{C}$ on a Micromeritics ASAP 2010 instrument to determine the Brunauer Emmett Teller (BET) surface area and to estimate the mesopore size distribution using the Barrett Joyner Halenda $(\mathrm{BJH})$ calculation procedure. Before each measurement, samples were evacuated overnight at 


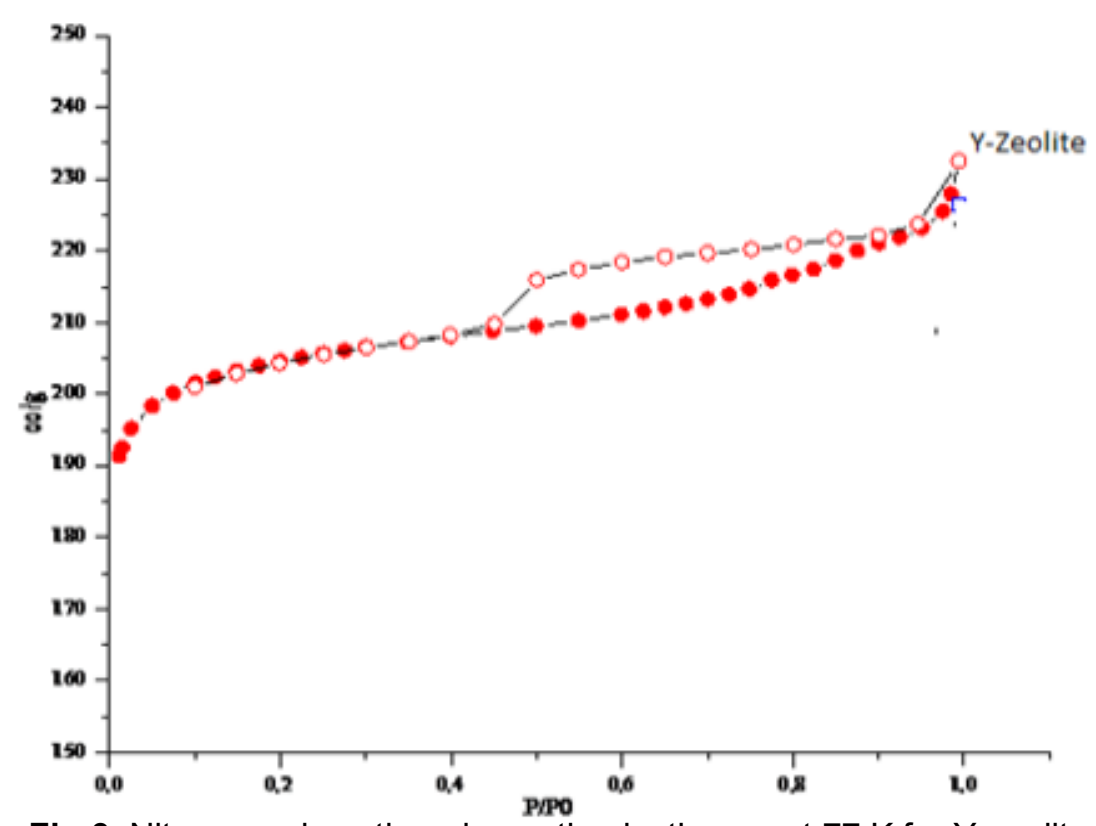

Fig 3. Nitrogen adsorption-desorption isotherms at $77 \mathrm{~K}$ for $\mathrm{Y}$-zeolite

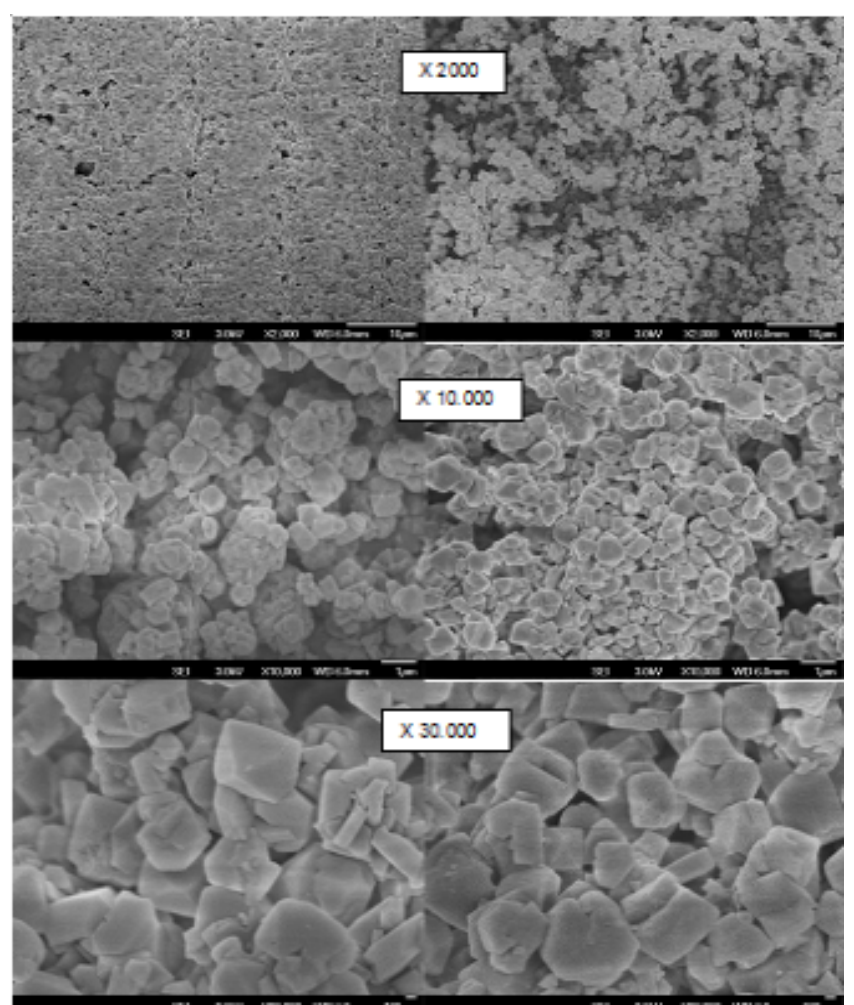

Fig 4. Scanning electron microscopy morphology from $\mathrm{Y}$-zeolite in different magnifications

Table 2. Textural properties of the Y-zeolite catalyst

\begin{tabular}{lc}
\hline Properties & $619\left(\mathrm{~m}^{2} / \mathrm{g}\right)$ \\
\hline $\mathrm{S}_{\mathrm{BET}}$ & $0.087\left(\mathrm{~cm}^{3} / \mathrm{g}\right)$ \\
$\mathrm{Vp}$ & $27.05(\AA)$ \\
$\mathrm{Dp}$ BJH method & \\
\hline
\end{tabular}

$100{ }^{\circ} \mathrm{C}$. Higher temperatures were not used so that occluded template in the zeolite structure would not decompose or volatilize. The gas $\mathrm{N}_{2}$ adsorptiondesorption isotherm for $\mathrm{Y}$-zeolite is shown in Fig. 3. This isotherms figure indicates that it is an excellent microporous material. The initial adsorption step at low relative pressure indicates complete filling of the mesopores on the sample. The Y-zeolite exhibited a BET surface area as high as $619 \mathrm{~m}^{2} \mathrm{~g}^{-1}$ and micropore volume of $0.087 \mathrm{~cm}^{3} \mathrm{~g}^{-1}$ was determined by the t-plot method and the micropore diameter was determined to be 27.05 Å using BJH method (Table 2).

\section{The morphology of the Y-zeolite by scanning electron microscopy, SEM}

Fig. 4 shows the SEM micrograph of the $Y$-zeolite (magnification $\times 2,000, \times 10,000$ and $\times 30,000)$. The micrograph is a characteristic image of a granulated surface on the zeolite powder particle. These observations are part of the silica on the $\mathrm{Y}$-zeolite external surfaces.

\section{Test Catalyst}

\section{Effect of the reaction time}

Effect of reaction time on the $\alpha$-pinene conversion and selectivity of terpineol is shown in Table 3 . To achieve a well mixing between the reagents and the $\alpha$ pinene during reaction, they must be stirred well at constant rate. The $\alpha$-pinene conversion increased rapidly with the reaction time ranges between $30 \mathrm{~min}$ until $60 \mathrm{~min}$, after that the conversion kept rising very 
Table 3. Products distribution over Y-zeolite catalyst

\begin{tabular}{rccccccc}
\hline \multirow{2}{*}{$\begin{array}{c}\text { Time } \\
\text { (min) }\end{array}$} & \multicolumn{9}{c}{ Products (\%) } & \multirow{2}{*}{$\mathrm{C}(\%)$} & $\mathrm{S}(\%)$ \\
\hline 10 & 53.59 & 2.89 & 4.20 & 7.93 & 24.45 & 46.41 & 52.68 \\
20 & 43.04 & 2.81 & 5.41 & 9.54 & 32.47 & 56.96 & 57.00 \\
30 & 38.29 & 3.28 & 5.89 & 3.89 & 35.38 & 61.71 & 57.33 \\
60 & 16.17 & 4.59 & 11.63 & 8.76 & 49.63 & 83.83 & 59.20 \\
120 & 7.99 & 4.63 & 12.75 & 11.49 & 49.82 & 92.01 & 54.15 \\
240 & 0.24 & 2.73 & 16.06 & 16.6 & 31.98 & 99.76 & 32.06 \\
\hline
\end{tabular}

Reaction conditions: $1.84 \mathrm{mmol}$ a-pinene, $2.5 \mathrm{~mL} \mathrm{H} 20,3.4 \mathrm{~mL}\left(\mathrm{CH}_{3}\right)_{2} \mathrm{CHOH}, 400 \mathrm{mg} \mathrm{Y-Zeolite,} \mathrm{temperature} 65^{\circ} \mathrm{C}$

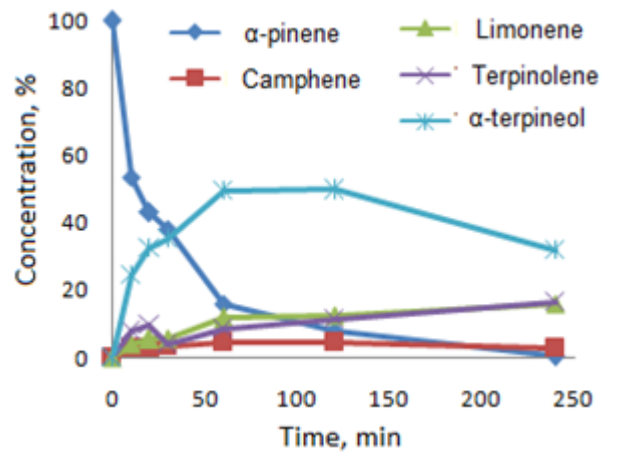

Fig 5. Concentration of reagents and products over Yzeolite catalyst vs. Time. Reaction conditions: $1.84 \mathrm{mmol}$ a-pinene, $2.5 \mathrm{~mL} \mathrm{H} \mathrm{H}_{2}$, $3.4 \mathrm{~mL}\left(\mathrm{CH}_{3}\right)_{2} \mathrm{CHOH}, 400 \mathrm{mg} \mathrm{Y}$ zeolite, temperature $65^{\circ} \mathrm{C}$

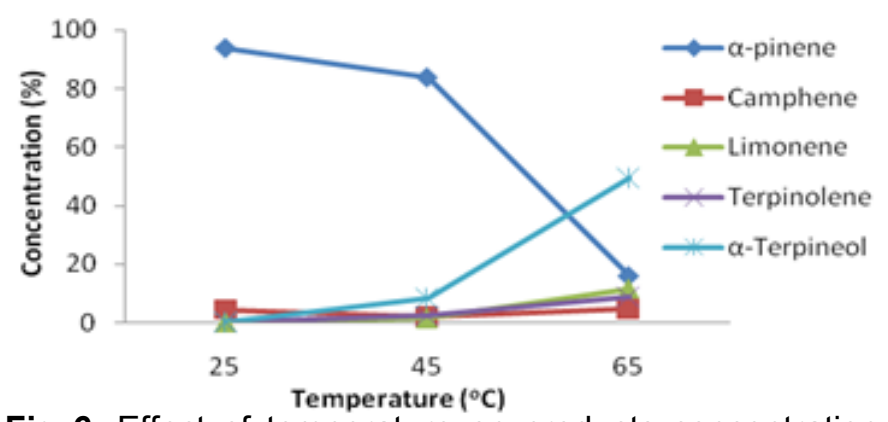

Fig 6. Effect of temperature on products concentration profile. Reaction conditions: $1.84 \mathrm{mmol}$ a-pinene, $2.5 \mathrm{~mL}$ $\mathrm{H}_{2} \mathrm{O}, 3.4 \mathrm{~mL}\left(\mathrm{CH}_{3}\right)_{2} \mathrm{CHOH}, 400 \mathrm{mg}$ Y-zeolite at $60 \mathrm{~min}$

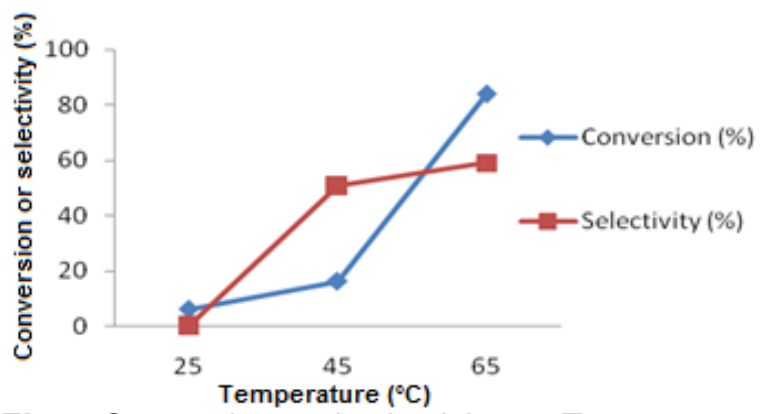

Fig 7. Conversion and selectivity vs. Temperature

slowly and then relatively constant at a value above $99 \%$ for $120 \mathrm{~min}$. The production of $\alpha$-terpineol reached the maximum value at $60 \mathrm{~min}$ (selectivity $59.20 \%$ ). Concentration of reagents and product over Y-zeolite catalyst vs. Time is shown in Fig. 5. It was observed in this study that the main products were a-terpineol, camphene, terpinolene, and limonene. Castanheiro et al. [5] proposed reaction scheme for the acid catalyzed hydration of $\alpha$-and $\beta$-pinene. They used molybdophosphoric acid as catalyst and obtained limonene, $y$-terpinolene, and $\alpha$-terpineol as main products. Since the same main products were found in this work, the similar evolution as the one shown in Table 3 could take place in the reaction using Y-zeolite as catalyst. Mochida et al. [9] reported the use of zeolites and obtained $100 \%$ conversion but with low selectivity for alcohols (about $57 \%$ ) for $240 \mathrm{~min}$. Avila et al. [2] used the catalysts $\mathrm{TCA} / \mathrm{ZrO}_{2} \cdot \mathrm{nH}_{2} \mathrm{O}$ in conversion of a-pinene into hydrocarbons with conversion of $57 \%$ and selectivity of $75 \%$ of total alcohol and it showed $57 \%$ selectivity for a-terpineol for $300 \mathrm{~min}$.

\section{Effect of reaction temperature}

In this work, hydration reaction was studied using $1.84 \mathrm{mmol} \alpha$-pinene and $2.5 \mathrm{~mL}$ water, weight of catalyst $400 \mathrm{mg}$, with three different temperatures $(25$, 45 , and $65{ }^{\circ} \mathrm{C}$ ). Effect of temperature on products concentration profile is shown in Fig. 6. It was observed in this study that the main products were terpineol, camphene, a-terpinolene, and limonene. The results showed that the reaction was typically exothermic, when temperature increased. Conversion and selectivity of hydration reaction of $\alpha$-pinene to terpineol as function of temperature was presented in Fig. 7. The maximum conversion was reached at temperature $65^{\circ} \mathrm{C}$. The hydration reaction at different temperatures was also studied by Patricia et al. [7]. He was studied the hydration of a-pinene using $\mathrm{PW} / \mathrm{SiO}_{2}$ with three temperatures $\left(15,25\right.$, and $\left.40{ }^{\circ} \mathrm{C}\right)$. Pakdel et al. [14] were studied the hydration of $\alpha$-pinene and water using sulphuric acid catalyst and acetone as solvent at different temperatures. When the temperature of the oil bath was maintained at $70-75{ }^{\circ} \mathrm{C}$, product of hydration was significantly lower then the oil bath temperature was set at $80-85{ }^{\circ} \mathrm{C}$. The hydration product of distribution was also found to be dependent on the reaction temperature. 


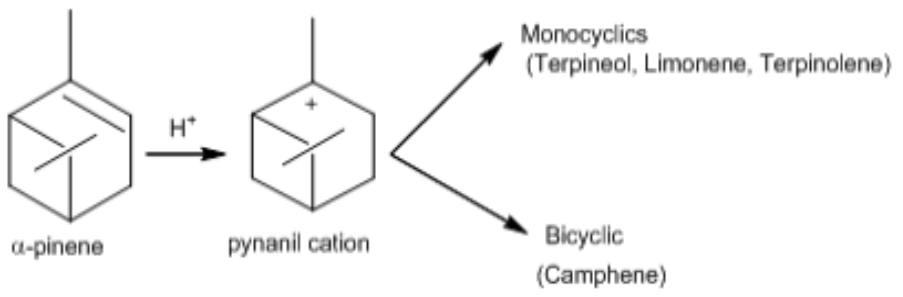

Fig 8. The acid catalyzed reaction scheme of $\alpha$-pinene

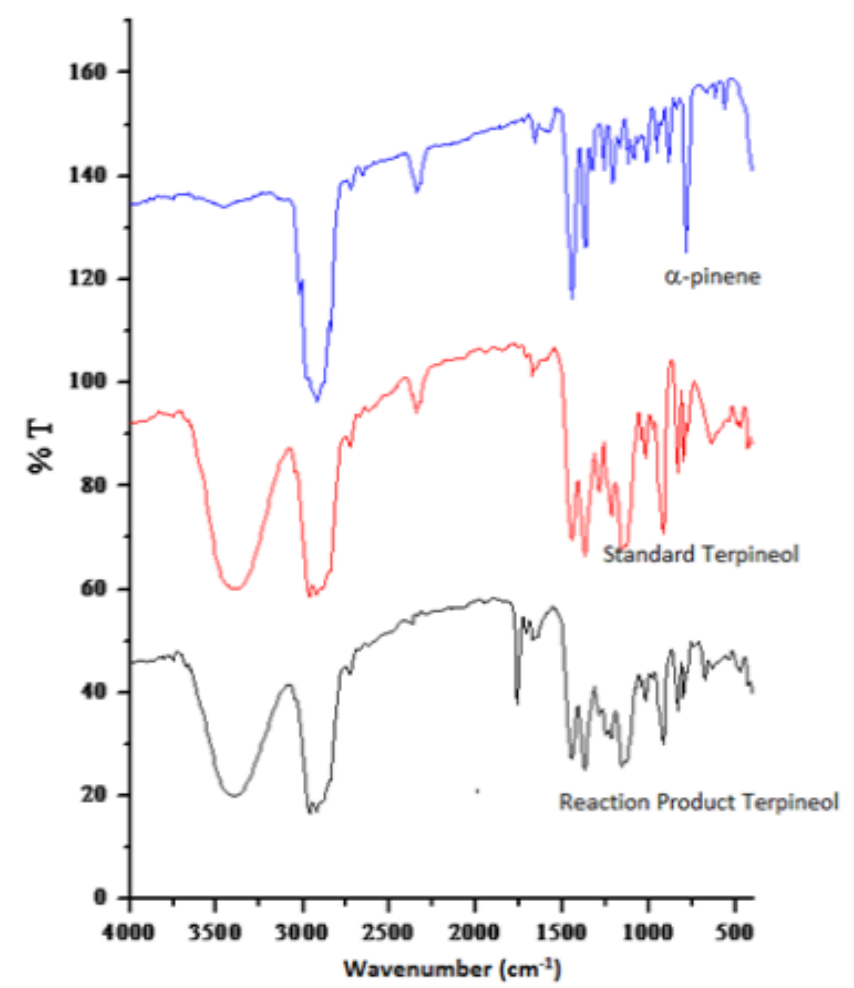

Fig 9. FT-IR Spectra of a) a-pinene; b) Terpineol standard; c) Terpineol (Product Reaction)

The acid catalyzed the hydration reaction of alkenes in aqueous solution (Fig. 8). The acid transfers a proton to double bond of the alkene forming an intermediate of carbocation. The carbocation can lose a proton and generate monocyclic and bicyclic hydrocarbons or, in the presence of a nucleophile, give to monocyclic and bicyclic alcohol $[2,8]$. In the hydration of terpenes, variation products might be obtained depending on the catalyst and reaction conditions.

The presence of $-\mathrm{OH}$ in the product was studied by FTIR [11]. Fig. 9 showed the spectra of a-pinene, standard terpineol and terpineol as a product of hydration reaction of a-pinene using Y-zeolite catalyst. The spectrum of a-terpineol as the hydration product exhibited diagnostic bands. Band at $3363 \mathrm{~cm}^{-1}$ was observed to stretching of the hydroxyl group of terpineol. The band at $1674 \mathrm{~cm}^{-1}$ and $1373 \mathrm{~cm}^{-1}$ were assigned to $\mathrm{C}=\mathrm{C}$ bond of the alkene system and $-\mathrm{CH}_{3}$ group. Finally, the bands came from stretching and bending of $\mathrm{C}-\mathrm{O}$ bond ( $\mathrm{C}-\mathrm{O}$ at the tertiary alcohol) were observed at $1157 \mathrm{~cm}^{-1}$ and $1126 \mathrm{~cm}^{-1}$.

The catalyst of Y-zeolite $(\mathrm{Si} / \mathrm{Al}=2.89)$ was studied for this reaction and the results were shown in Table 3. The internal surface of Y-zeolite being highly hydrophobic possesses affinity towards non polar molecules like that of $\alpha$-pinene [13]. Y-Zeolite showed high activity for a-pinene hydration, indicating the high potential of this catalyst as an alternative solid acid catalyst to conventional homogeneous catalyst. By evaluating this work, Y-zeolite was a good candidate for the industrial hydration of $\alpha$-pinene, due to its easy separation from reaction products and low cost.

\section{CONCLUSION}

Y-zeolite was found as good catalyst for the production of a-terpineol from $\alpha$-pinene. The higher selectivity was $59.20 \%$ with a conversion of $83.83 \%$ after $60 \mathrm{~min}$ at $65^{\circ} \mathrm{C}$. The obtained yield with using this catalyst was useful for industrial application mainly due to the easy separation and purification of this catalyst from the reaction media.

\section{ACKNOWLEDGEMENT}

The authors would like to thank Directorate General of Higher Education (DGHE), Department of National Education Republic Indonesia for the grant. The authors thank to Assoc. Prof. Chuah Gaik Kuan, Department of Chemistry, Faculty of Science, National University of Singapore (NUS) for assistance with sample characterization.

\section{REFERENCES}

1. Bhatia, S.P., McGinty, D., Foxenberg, R.J., and Letizia, C.S., 2008, Food Chem. Toxicol., 46, 11, Suppl., S275-S279.

2. Ávila, M.C., Cornelli, N.A., Rodríguez-Castellón, E., Jiménez-López, A., Flores, R.C., Ponzi, E.N., Ponzi, M.I., 2010, J. Mol. Catal. A: Chem., 322, 12, 106-112.

3. Yuasa,Y., and Yuasa, Y., 2006, Org. Process Res. Dev., 10, 6, 1231-1232.

4. Vital J., Ramos, A.M., Silva, I.F., and Castanheiro, J.E., 2001, Catal. Today, 67, 1-3, 217-223.

5. Castanheiro J.E., Fonseca, I.M., Ramos, A.M., Oliveira, R., and Vital, J., 2005, Catal. Today, 104, 2-4, 296-304.

6. Yadav, M.Kr. Patil, M.V., and Jasra, R.V., 2009, J. Mol. Catal. A: Chem., 297, 2, 101-109. 
7. Robles-Dutenhefner, P.A., da Silva, K.A., Siddiqui, M.R.H., Kozhevnikov, I.V., and Gusevskaya, E.V., 2001, J. Mol. Catal. A: Chem., 175, 1-2, 33-42.

8. Román-Aguírre. M., De la Torre-Sáenz, L., Flores, W.A., Robau-Sánchez, A., and Elguézabal, A.A., 2005, Catal. Today, 107-108, 310-314.

9. Mochida T., Ohnishi, R., Horita, N., Kamiya, Y., and T., Okuhara, 2007, Microporous Mesoporous Mater., 101, 1-2, 176-183.

10. Santos, M.G., and Morgado, A.F., 2005, Alpha Terpineol Production from Refined Sulfate Turpentine, $2^{\text {nd }}$ Mercosur Congress on Chemical
Engineering, $4^{\text {th }}$ Mercosur Congress on Process Systems Engineering, ENPROMER, Costa verde Rio de Janeiro, Brazil.

11. Kazansky V.B., Subbotina, I.R., and Jentoft, F., 2006, J. Catal., 240, 1, 66-72.

12. Zhang, H., Mahajani, S.M., Sharma, M.M., and Sridhar, T., 2002, Chem. Eng. Sci., 57, 3, 315-322.

13. Zhao Y., and Truhlar, D.G., 2008, J. Phys. Chem. C, 112, 17, 6860-6868.

14. Pakdel, H., Sharron, S., and Roy, C., 2001, J. Agric. Food Chem., 49, 9, 4337-4341. 